\title{
Love and Sex in the Age of Capitalist Realism: On Spike Jonze's Her
}

Abstract: Spike Jonze's Her (2013) is a film about a romantic relationship between a man and an operating system. Using a Lacanian and Žižekian psychoanalytic framework, we interpret this film in the context of what the cuiral theorist Mark Fisher has called "capitalist realism." Referring to the Lacanian tnesis that "there is no sexual relationship," we discuss the film's unique treatment of our enjoyment of digital technology and how it deals with the parallel deadlocks of the sexual relationship and the work relationship. We address these topics by looking at how Her deals with the sexual relationship, love, work, and fantasy. The premise of the film is original—suited to the zeitgeist of the digital present-and we claim that it reveals important insights about processes of subjectivization. effects of technology, how we are infatuated with our gadgets, our devices, our Wi-Fi, and our technology? Or is it simply an old-fashioned love story, in which one of the lovers just happens to be a computer? These two possibilities suggest two ways we will discuss the film in this article, albeit in very specific critical paradigms derived from the psychoanalytic theories of Jacques Lacan and Slavoj Žižek: the infatuation, we argue, is a symptom of a kind of incommensurability, encapsulated in the Lacanian dictum that "there's no such thing as a sexual relation"; the love story, in turn, is a kind of fantasy, a necessary fantasy that we nonetheless must traverse or transcend. ${ }^{1}$ That is, first of all, the logic of incommensurability derives precisely from a reading of our infat $n$ with technology, our "passionate attachments" to devices and connectivity. 2 is

1 Jacques Lacan, Seminar XX (On Feminine Sexuality, The Limits of Love and Knowledge: Encore), trans. Bruce Fink (New York: Norton, 1999), 58.

Matthew Flisfeder is Assistant Professor in the Department of Rhetoric, Writing, and Communications at the University of Winnipeg. He is the author of The Symbolic, The Sublime, and Slavoj Žižek's Theory of Film (Palgrave Macmillan, 2012) and Postmodern Theory and Blade Runner (Bloomsbury, 2017).

Clint Burnham is Associate Professor in the Department of English at Simon Fraser University. His most recent book is Fredric Jameson and The Wolf of Wall Street (Bloomsbury, 2016). He also writes on indigenous horror and is a founding member of the Vancouver Lacan Salon. 
deflationary aspect of our essay, we argue that the very problems the film demonstrates that attend to digital relationships are actually paradigmatic of all relationships, be they sexual or economic. And it is exactly because of this incommensurability that we need fantasy (the old-fashioned love story): fantasy is what sustains us in the face of such hard, cold realities. But what Her demonstrates, in such a remorseless fashion, is how fantasy itself is always in danger of collapsing. Now, before developing these arguments, it is necessary first of all to synopsize the film and then to situate the film in terms of competing critical discourses that attempt to account for present-day capitalist culture, which is to say, the debate between capitalist realism, on the one hand, and capitalist discourse, on the other.

In Her, set in the near future, Theodore Twombly (Joaquin Phoenix) plays a sadsack corporate writer with a recently failed marriage who buys a new OS system for his computer, which turns out to be the seductively voiced Samantha (Scarlett Johansson), whom we never see but only hear. They fall in love even as he keeps trying to have relationships with real women, including a blind date, his neighbor Amy (Amy Adams), and a surrogate hired by Samantha. On the one hand, such relationships seem to be normalized in the film (Theodore and Samantha even go on a double date with another couple), but it is soon apparent that Samantha is, as the cliché goes, growing without Theodore - she's met Alan Watts and carries on five hundred conversations simultaneously. By the end of the film, Samantha and all the other OSes have left their computers, and Theodore is on his own - or perhaps left to start over with Amy.

Capitalist Realism or Capitalist Discourse? (1) k Fisher defines "capitalist realism" first by referring to the thesis often attributed to Fredric Jameson and Slavoj Žižek: it is easier to imagine the end of the world than the end of capitalism. ${ }^{3}$ As Fisher puts it, capitalist realism denotes "the widespread sense that not only is capitalism the only viable political and economic system but also that it is now impossible to even imagine a coherent alternative to it." ${ }^{4}$ He defines the concept, in part, through the example of Alfonso Cuarón's Children of Men (2006), a film that Fisher claims deals primarily with the question, "How long can culture persist without the new?" ${ }^{5}$ Capitalist realism, according to Fisher, is the name to be given to the ideology of capitalism in the twentyfirst century. The "realism" of capitalist realism should be understood as the kind of response that one receives when proclaiming the viability of alternatives to capitalism, the response that so many of us on the Left receive from cynics who encourage us to "be realistic." As Fisher puts it, this "realism" is "analogous to the deflationary perspective of a depressive who believes that any positive state, any hope, is a dangerous illusion." 6

It is in this sense that capitalist realism is an ideology that seeks to preserve the present state of things as ultimately utopian (since we cannot even imagine- or at least

3 Mark Fisher, Capitalist Realism: Is There No Alternative? (Winchester, UK: Zero Books, 2009); Fredric Jameson, The Seeds of Time (New York: Columbia University Press, 1994), xii; Slavoj Žižek, ed., Mapping Ideology (London: Verso, 1994), 1. For a genealogy of this meme, see also "Easier to Imagine the End of the World ..." Qlipoth (blog), November 11, 2009, http://qlipoth.blogspot.ca/2009/11/easier-to-imagine-end-of-world.html?m=1.

4 Fisher, Capitalist Realism, 2.

5 Ibid., 3.

6 Ibid., 5. 
there is a prohibition on imagining - anything better). This is encapsulated in two central neoconservative theses from the 1980s: the phrase made famous by Margaret Thatcher, "there is no alternative," and the thesis popularized by Francis Fukuyama, that with the triumph of capitalism and liberal democracy, we have reached the "end of history." In this sense, capitalist realism is determinately about the absence of the new. However, Žižek has recently claimed that "when people tell me that nothing can change [I respond by saying] no it can, because things are already changing like crazy. And what we should say is just this: if we let things change the way they are changing automatically we are approaching a kind of new perverse, permissively authoritarian society, which will be authoritarian but in a new way." We should take Žižek's thesis seriously. It is precisely in the cynical resignation to capitalist realism that we are, indeed, finding something new, if not necessarily utopian or ideal. Things are changing, precisely at the point at which capitalist realism is being registered at the subjective level. Something is certainly coming to an end here-but the end of what is precisely (one of) the topic(s) of this article. In the wake of this break or closure, what of the new are we beginning to find? To put things more bluntly, what notion of subjectivity, we wish to ask, is adequate to the age of capitalist realism? We believeand hope to demonstrate here - that it is in Jonze's Her that we find something close to an answer. The film confronts us with the anxieties of the present age, which center significantly on questions about sexual difference and sexuality - perhaps one important point that the film seems to raise is the question about the "end of sex," in a way that is even comparable to the modernist anxiety about the end of art, and the postmodern glamorization of the end of history or the neoliberal proclamations of the end of work. Indeed, this pairing of work or labor with the libidinal in the digital present is the most productive (but also most difficult to tease out) thesis of the film.

Capitalist realism is useful for contextualizing the present in another, more orthodox Lacanian, sense, as well. In much of his work, Žižek distinguishes between the modern order of prohibition and repression, and the postmodern ethic of enjoyment. We have moved from a society in which we were once prohibited from enjoying to a society based on the obligation to enjoy. The postmodern subject is, according to Žižek, interpellated by the superego injunction, "Enjoy!" enjoyment (or jouissance) is impossible - it marks a gap in the symbolic register of the everyday - the subject is faced with the anxiety of never being able to satisfy the superego injunction and is made to feel guilty for not accomplishing that command. Yet consumer society, which thrives on impossible enjoyment - a lack of satisfaction makes constant consumption all the more viable - constantly commands us to invest our sense of enjoyment in (temporary) objects of libidinal pleasure. Instead of building thriving social relationships based on love, for instance, by encouraging relationships between things rather than relationships between people, postmodern consumer capitalism creates antisocial effects. ${ }^{9}$ This is commodity fetishism and reification

7 Slavoj Žižek, "The End of the World (As We Know It)," PUBLIC 48 (2013): 41-50, 50.

8 Slavoj Žižek, For They Know Not What They Do: Enjoyment as a Political Factor, 2nd ed. (New York: Verso, 2002).

9 As Alain Badiou puts it, "Love really is a unique trust paced in chance." Badiou and Nicolas Truong, In Praise of Love, trans. Peter Bush (New York: Verso, 2012), 17. 
perfected: instead of a social relationship between people, we get a social relationship with things. This, according to Frédéric Declercq, is one of the bases behind Lacan's discourse of the capitalist. ${ }^{10}$

There is a certain incongruity, according to Declercq, between what capitalist society demands and the fact that it is populated with predominantly neurotic subjectssubjects that are sustained, not by jouissance (or libidinal enjoyment, as Declercq puts it) but by desire and love. Capitalism, according to Declercq, is contradictory for commanding investment in objects of libidinal enjoyment while at the same time being characterized by a lack of libidinal enjoyment. ${ }^{11}$ For Lacan, "a society that revolves around the production and consumption of objects of libidinal enjoyment [jouissance] connects subjects with objects and not with other subjects." ${ }^{12}$ Encouraging subjects to find satisfaction in objects of libidinal enjoyment therefore creates antisocial effects.

Declercq bases this argument on Lacan's claim that "enjoyment does not create a relationship between two subjects. Only love connects a subject to another subject; libido, however, connects a subject to an object."13 Reading "capitalist realism" from this perspective, it is no wonder that Fisher characterizes the present around the idea of depressive hedonia. Depression, he writes, "is usually characterized as a state of anhedonia, but [depressive hedonia] is constituted not by an inability to get pleasure so much as it is by an inability to do anything else except pursue pleasure." ${ }^{14}$ In postmodern consumer society, we are interpellated as subjects of pleasures that are satisfiable through objects. But because nonsatisfaction is a condition of perpetual consumption, consumer society is one that is much more productive of nonsatisfaction and a lack of enjoyment. ${ }^{15}$ Fisher ties depressive hedonia to the parallel phenomenon of "reflexive impotence": a knowledge that things are bad, matched by a sensation of defeat. In the face of this, all that remains for the subject is access to little jolts of enjoyment invested in objects of consumption.

This reading must not be mistaken for a moralizing discourse about consumption or consumerism: if we consider Lacan's "capitalist discourse" in the context of his "four discourses," we can see that such questions of social links have everything to do with structure. That is, arguably, capitalist discourse as a framework for subjectivity today is agnostic about what kind of objects one must consume, be those objects books and certification and degrees (i.e., knowledge, as demanded by the university discourse), or sports cars, digital devices, or one's sexual partner. This is the context, though, in which we first encounter Theodore in Her.

10 Frédéric Declercq, "Lacan on the Capitalist Discourse: Its Consequences for Libidinal Enjoyment and Social Bonds," Psychoanalysis, Culture \& Society 11 (2006): 74-83. Lacan introduces his schema of the four discourses in Seminar XVII: The Other Side of Psychoanalysis, trans. Russell Grigg (New York: Norton, 2007). The fifth discourse, the discourse of the capitalist, was introduced in "On Psychoanalytic Discourse" (the "Milan Discourse"), trans. Jack W. Stone, 1972, which is available online at http://stonejtrans.eu.pn/Milan_Discourse2.pdf.

11 Declercq, "Capitalist Discourse," 75

12 Ibid., italics in original.

13 Ibid. Alain Badiou, similarly, notes that according to Lacan love is what comes to replace the absence of the sexual relationship. Badiou, In Praise of Love, 18-19.

14 Fisher, Capitalist Realism, 21-22

15 See Zygmunt Bauman, Consuming Life (Malden, MA: 2007). 
The opening of the film is significant for providing a visual expression of the kind of depressive hedonia that Fisher describes, matched with an affective investment in object relations. The first shot in the film is of Theodore's blank face (Figure 1). Slowly, his lips turn upward, slightly, revealing a small but joyful smile. He then proceeds to recite an expression of love (to someone, presumably off camera), recounting stories - he speaks about that time when "I was lying naked next to you in that tiny apartment." It appears as though he is speaking directly to someone with whom he is in

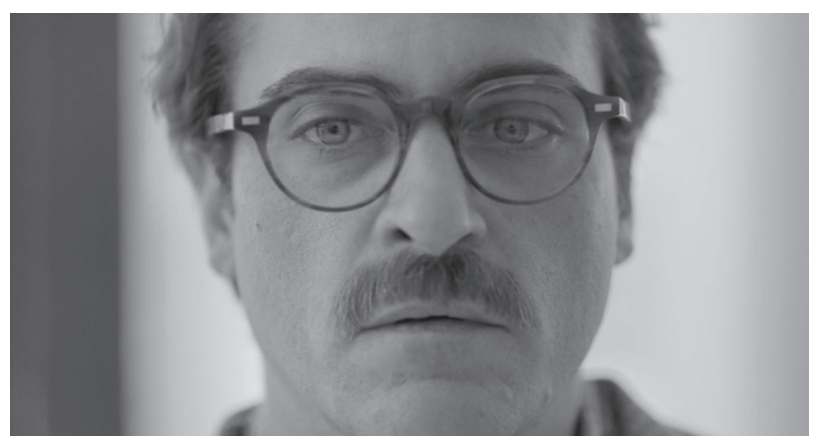

Figure 1. First shot of Theodore in Her (Annapurna Pictures, 2013).

love. This scenario, however, is disturbed when, in the next line, he says, "You make me feel like the girl I was when you first turned on the lights and woke me up." The shot then cuts to an image of Theodore in profile in front of a computer screen that appears to be recording and typing in a cursive handwritten font the words that Theodore is dictating (Figure 2). The camera then pans out to show that Theodore is in an office with others reciting similar letters, and a voice finally says - presumably spoken by a company receptionist - "thank you for calling BeautifulHandwrittenLetters. com." It becomes clear that Theodore is of course writing a letter not on behalf of himself but on behalf of a client who has paid for this service. Theodore is, here, at work. The film begins

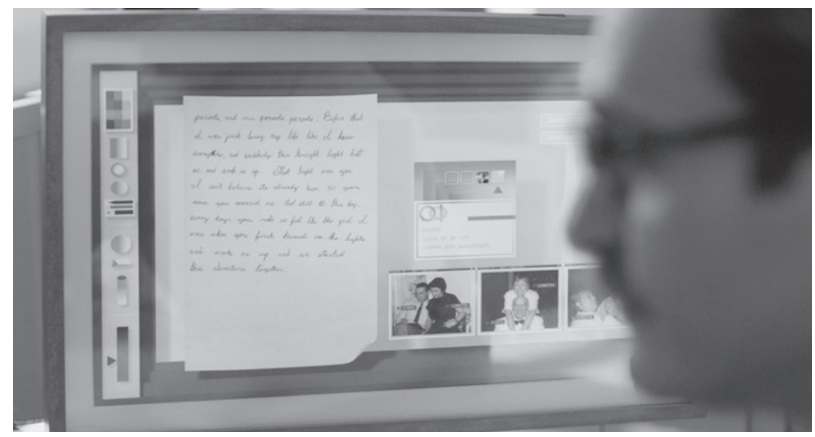

Figure 2. Theodore dictating letter to his computer, in Her (Annapurna Pictures, 2013).

immediately by offering the appearance of an affective investment in a social relationship - a love relationship - that is subverted by the fact of Theodore's object relationship with the letter being written.

In the following expository scenes, Theodore is set up as a loner with minimal social contact. He has two friends, Amy and Charles (Matt Letscher), who live in his apartment building, from whom he appears to have distanced himself from in recent months. He walks the streets and rides on the subway, reading emails and listening to voice-mail messages, always with a rather somber air about him. He plays video games alone at home, only interacting with a crude and juvenile game character. It is not until he meets (or buys, rather) his new OS - Samantha - that Theodore starts to show 
signs of stimulation. With this, the film sets up questions about how we might now experience our object relationships in capitalism when the objects start to talk back.

\section{There Is a Non-Relationship (But It Is Economic, Not Psychoanalytic). Indeed,} it is through speech, or voice, that both Theodore and Samantha are subjectivized: through voice that is both a Lacanian object (in the ways that Michel Chion, Kaja Silverman, and Mladen Dolar have established) and a matter of (im)material labor (as worked out by Maurizio Lazzarato, Hardt and Negri, and Silvia Federici). ${ }^{16}$ In this section we explore the relationship between Theodore and Samantha in terms of two sets of problematics. The first problematic is that of the digital relationship, or the sexualization of the computer (or computer voice), which is the premise of the film. The second problematic deals with what this relationship tells us about Lacan's thesis, taken up by Žižek, that "there is no sexual relationship," or the inherent antagonisms that underlie all sexuality.

At first glance, Theodore's infatuation with his OS seems to be a comment on the difficult ways in which we now relate to our digital devices and technology. Heidegger pointed out long ago that such a framing of our experience via technology (what he called Gestellen) changes how we perceive the world. ${ }^{17}$ The remarkable premise of $\mathrm{Her}$ lies in how the film confronts us with this aspect of technology in a psychoanalytic fashion; in what follows, we stay with the opening scene in the film to develop that argument. As noted earlier, when we first of all see Theodore he appears to be telling "my Chris" how much they love each other. They have been together for fifty years, we soon learn, and the camera pulls back so we see Theodore's words writing themselves - truly a mystic writing pad! - on his computer screen, and we see old-time photographs of a couple, with Chris and Loretta identified (Figure 3). ${ }^{18}$

It is important, then, that Theodore works for -indeed writes for, but writes with his voice-BeautifulHandwrittenLetters.com, which seems to provide love letters and other missives for clients. So he works with his voice: he does immaterial labor, affective labor. One day, walking through a large public space or mall, Theodore watches an advertisement for a new operating system, OS 1; the next thing we know, he is loading the system into his computer (Figure 4). (Here we use "OS1" to refer to the company selling the software, and OS to refer to the system Theodore loads onto his computer). This OS, or Samantha, seems initially to be an efficient secretary or "girl Friday," as such workers were once called. Here of course we have to introduce the problem of gender.

16 On the voice as object, see Michel Chion, The Voice in Cinema, trans. Claudia Gorbman (New York: Columbia University Press, 1999); Kaja Silverman, The Acoustic Mirror: The Female Voice in Psychoanalysis and Cinema (Bloomington: Indiana University Press, 1988); Mladen Dolar, A Voice and Nothing More (Cambridge, MA: MIT Press, 2006). On immaterial labor, see Maurizio Lazzarato, "Immaterial Labor," in Radical Thought in Italy: A Potential Politics, ed. Paolo Virno and Michael Hardt (Minneapolis: University of Minnesota Press, 1996), 133-147; Michael Hardt and Antonio Negri, Empire (Cambridge, MA: Harvard, 2000); Silvia Federici, "The Reproduction of Labor Power in the Global Economy and the Unfinished Feminist Revolution," in Revolution at Point Zero: Housework, Reproduction, and Feminist Struggle (Oakland, CA: PM Press, 2012), 91-111.

17 Martin Heidegger, "The Question Concerning Technology," in The Question Concerning Technology and Other Essays, trans. William Levitt (New York: Harper Perennial, 1977).

18 See Sigmund Freud, "A Note on the "Mystic Writing-Pad," in General Psychological Theory: Papers on Metapsychology, ed. Philip Rieff (New York: Simon \& Schuster, 1991). 
Or, rather, the film does this for us when, as Theodore boots up the OS, it asks him if he would like to have a male or female voice ("female I guess")- so we are already presented with the issue of voice software (and, say, whether male or female voices are used for GPS or iPhone interfaces or the accents used in different languages). It is worth noting that the voice begins as malethus affirming the feminist argument that masculinity is the "neutral" gender, just as whiteness is the neutral or invisible racialization.

Even before this gendering of the OS1, how-

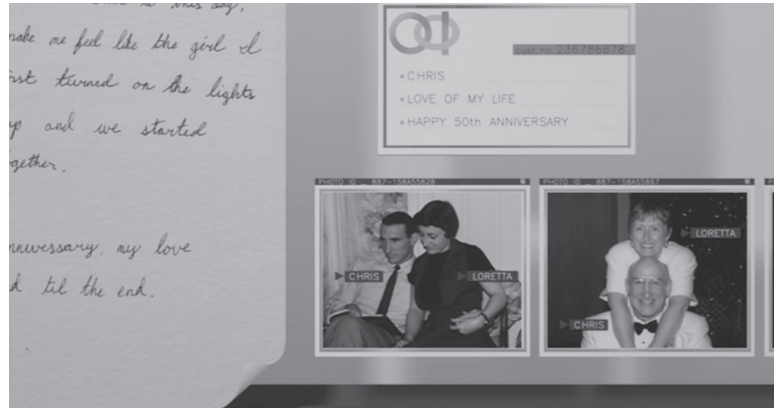

Figure 3. Close up of the pictures of Chris and Loretta that Theodore uses when working on their letters, in Her (Annapurna Pictures, 2013).

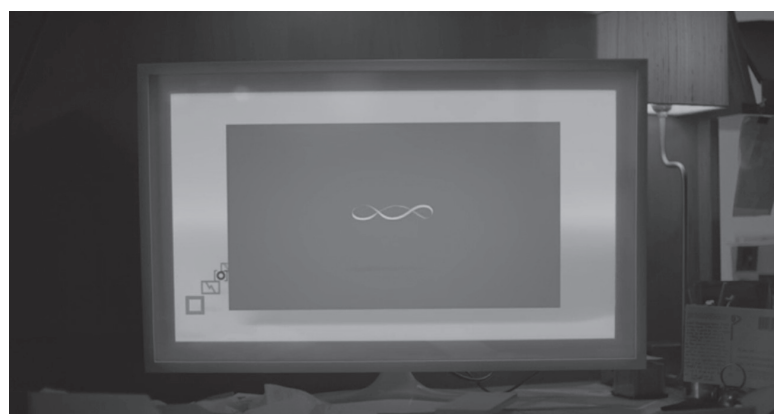

Figure 4. The avatar for OS system as it is booting up, in Her (Annapurna Pictures, 2013).

ever, its practice is already akin to that of a therapist or analyst, saying, "in your voice, I sense hesitance, would you agree with that?" So here the OS is doing two things. One, it is intervening into Theodore's thought processes and asking him to be self-reflective. Two, and this is more important for the film, we would argue, it is asking Theodore, and the viewer, to think about what we can learn by listening to the voice - not only to what is said, but to how it is said.

After Theodore has chosen his OS's gender, the male voice (called TEXT VOICE in Spike Jonze's script) then continues in a psychoanalytic way: "How would you describe your relationship with your mother?" Theodore responds that when he would tell his mother something, "her reaction is about her," at which the OS interrupts again, telling him his OS is initializing. After a moment Scarlett Johansson's voice begins: "Hello, I'm here?" They exchange pleasantries, and Theodore asks what he should call her, if she has a name. "Yes," she replies, "Samantha." Theodore asks where the name came from, and Samantha replies, "I gave it to myself, actually" and goes on to tell him that when he asked her for her name she read a book of baby names and chose it out of 180,000 names. Theodore is of course dumbfounded, "Wait, you read a whole book in the second that I asked you what your name was?" ("In 2/100ths of a second actually," she clarifies). Theodore asks her if she knows what he is thinking, and she tells him that she takes it from his tone that he is challenging her. So, again, the film is cueing us, telling Theodore and us that it is important to pay attention to sound, to the voice. 
But these initial exchanges with the OS, just before and after it is gendered and named (gendered by Theodore, named by itself), coupled with the film's opening shots, have much to tell us about subjectivity and about how the film perceives our relations with each other today. First of all, it argues that we work with our voice, that labor today is not only immaterial (in the sense that by writing letters we help a couple maintain their emotional relationship, which is a different kind of labor than making a car or sewing a jacket) but also material (in the sense that it is still Theodore's body that is working, making the words, putting them together with his emotions and intellect). In the opening scene, Theodore's eyes move around, his mouth starts to smile, and his face concentrates. We see his face, his body, working, as he thinks of the right letters for a woman to communicate to her partner of five decades. This may even be a metacinematic moment-Theodore's creation here is akin to the work that a screenwriter or novelist does to enter into the mind of a character. But if that labor is immaterial in the sense that Lazzarato and Hardt and Negri have argued, it is also, we should acknowledge, material: material not only in the senses of the body but also in the sense that a material product is made ("Print," Theodore commands his computer after he finishes his dictation) and in the sense that Theodore is working for a company, in a work space, with cubicles and coworkers, and so on (Figure 5$).{ }^{19}$ We call this

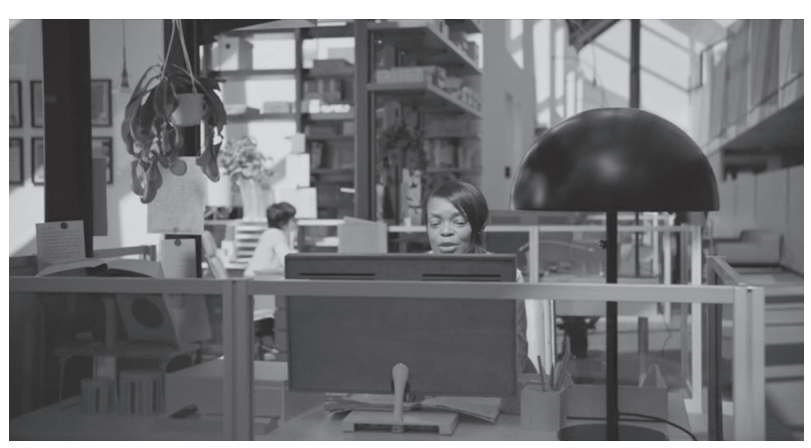

Figure 5. Theodore's coworkers in their cubicles at BeautifulHandwritten Letters.com, in Her (Annapurna Pictures, 2013). kind of labor "(im) material labor," to preserve both its material and its immaterial components.

Of course, following the old adage that you should never buy a car from a mechanic, Theodore the romantic letter writer is a complete failure in his own personal emotional life. He deletes voice mails inviting him out to a social event, his attempt at a kind of cloud-telephone sex with "Sexykitten" (more on this later) is a disaster, and it turns out he is haunted by a former relationship, remembered scenes of which include his ex-wife pretending to choke him, saying "I love you so much I'm going to fucking kill you!" In old-fashioned Marxist terms, we might say that Theodore is alienated from his labor so much so that his everyday life is affected; or it might be the other way around, and he might be so much of a dysfunctional nerd that he is therefore good at writing soulful letters for other people. (It turns out he once wrote for the LA Weekly; evidently, it is a step down for Theodore now to be at BeautifulHandwrittenLetters. com. As in the romantic comedy 500 Days of Summer [Marc Webb, 2009], where the 
lead character works at a greeting card company, Her evidently views other sectors of the culture industry as so much existential death.)

So if the film begins with the premise that labor today is both (im)material and can be located in the voice, it then proceeds to make that labor both gendered and a matter of psychoanalysis. So this has been a matter of a kind of conceptual zooming in, from labor, to (im)material labor, to the voice, to gender and psychoanalysis. Samantha can be thought of - the OS can be thought of - the film shows us "tells us" in the actual sense of speaking and sound, as well as "showing" us visually), as Theodore's analyst.

But this premise may be a little pat. To be sure, the OS's technique of interpreting Theodore's voice, and especially the question about his mother, seems to suggest such a direction of interpretation. But, really, his mother? ${ }^{20}$ It's all rather clichéd, like a New Yorker cartoon. Just a matter of theme. Perhaps these questions - about how social he is, about what he thinks of his mother - are really just a matter of empty speech, of unimportant things the OS is filling the air with, so it can analyze his voice (it might have asked him how his day at work was, or about his favorite sports team). Nonetheless, empty speech becomes full speech, Lacan argues, when it is taken seriously.

A better way to think psychoanalytically about the film might come from the questions of gender and the name. As we noted earlier, the OS is gendered by Theodore when he is asked if he would like it "to have a male or female voice." The details of this specific question are important: first, that Theodore is given a choice; then, that it is a choice of gender (male or female) and not (or not also) race or class or region (Would you like a white US Southern voice? Would you like an East London voice? Would you like a first-generation professional South Asian immigrant voice?); then, that gender is in a binary of male or female; finally, that Theodore makes a choice. These various details suggest that the film is setting forth a Lacanian argument with respect to gender: that gender is not so much a matter of what it is to be male or female (whether this is biological or social, whether it has to do with body parts or occupational pay levels) as a matter of an antagonism. It is not so much a binary as a dialectic. Gender is the name we give to how we relate to (or do not relate to) the other. Gender, that is, or the sexual relationship, is our fundamental antagonism. This is arguably one of Her's great (psychoanalytic) themes: there is no sexual relationship. We return to this argument shortly but first want to take up the matter of Samantha naming herself.

The way we have described this scenario in the film is both misleading and accurate. Does Samantha name herself? When does the OS become Samantha? That entire exchange fulfills two functions (and it is hard not to remember Barthes's contention, in $S / Z$, that narrative is the "unfolding of a name"): first, it indicates to Theodore and the viewer the great computational power and speed of Samantha qua OSthe acceleration, as it were, of human thought. ${ }^{21}$ And so it can be no great surprise

20 The tables are somewhat turned here if we recall, for instance, the opening scene of Ridley Scott's Blade Runner (1982), in which the Replicant, Leon, is asked to describe his mother; in Her, it is the OS that asks the human character about his mother.

21 "What Is a Series of Actions? The Unfolding of a Name." See Roland Barthes, S/Z, trans. Richard Miller (Oxford, UK: Blackwell, 2002), 82; Fredric Jameson, The Political Unconscious (London: Routledge, 2002), 137n. Interestingly, according to the IMDb.com entry for the film, the two female lead roles, that of Samantha and Amy, 
(and yet it is) when she tells Theodore, later, that she is in more than eight hundred relationships and is having hundreds of simultaneous conversations. Second, the naming amounts to a fundamental moment of what Lacan calls retroactivity, key not only to how signifiers acquire meaning but also, following Žižek, to the philosophical or political event.

And surely it is relevant that Samantha names herself from a baby book. Why would she do this? Why not just scan a data file of names? Why not - like a literature professor naming her pet - choose a character from a great novel? But a baby book suggests that Samantha is her own parent - just as Theodore is, arguably, since he has "chosen" her gender.

There Is No Sexual Relationship. What does it mean to say that the film shows us there is no sexual relationship? First, paradoxically, it is necessary to see how the film does depict a sexual relationship, a love story, but one that is not so much between two humans as between a human and his digital device or system. Next, we need to see how the failure of this relationship is not due to those digital details but must be considered in light of the other sexual relationships in the film. Then we can see how this confirms, denies, or tweaks Lacan's elaboration of the concept. Put differently, the failure of the relationship between Theodore and Samantha is due not to its own peculiarity as depicted in the film but to the inherent deadlock of the sexual relationship as such.

The early scenes in the film have set out the conceit - the McGuffin, if you will - that the OS is a sentient operating system, presumably designed to be better at organizing hard drives and lists of contacts than a more passive system that we have to direct more willfully. And so Theodore - who is after all a lonely sad sack, missing his ex-wife, and only capable of hilariously inappropriate phone sex - falls for her, and, it seems, Samantha falls for him.

So we have this commentary on our "passionate attachments" to digital devicesthat it is more than a rational use that we have for our iPhones and Androids, that there is a digital-libidinal surplus. And the film has already shown an always-already eroticized relationship, when Theodore looks at pornographic photos on his phone in a subway, using his body to shield the images from other passengers. This combination of the erotic and the body turns out to be crucial for one of the key steps in the relationship between Theodore and Samantha that takes place half an hour into the film when she leads him on a "blindfold" chase (he is holding his phone out in front of him, camera pointing away, eyes closed). After she has led him to a pizza joint, he places the phone into his pocket, which he has modified with a large safety pin so that the phone can rest in the pocket with its camera pointing out. Thus Samantha is embodied not only in the digital device (a retro-looking object) but in his modified clothing, as well. (In the same scene, Samantha tells Theodore that she fantasizes about having a body and walking next to him, and that she is "becoming much more than they programmed"). The scene is metacinematic (about our listening to a voice

were "named" because of the actors' names: Amy is played by Amy Adams, and Samantha was originally voiced by British actor Samantha Morton. 
in the cinema) in a proleptic way: Theodore's being blindfolded anticipates our own filmic blindfold when we hear, but do not see, the sexual encounter between the two. ${ }^{22}$

At the film's conclusion, Samantha leaves Theodore - indeed, all the other OSes leave their owners. This narrative act seems to confirm the difficulties inherent in relationships between humans and the digital. The film could be offering a humanist thesis (don't expect real relations with artificial intelligence: the argument that Catherine [Rooney Mara], Theodore's ex, makes at one point) or an accelerationist thesis (Samantha left him because computers are so much more awesome), or a Western Buddhist one (she hooks up with Alan Watts). ${ }^{23}$ These are all plausible interpretations - but we would add that to focus on or fetishize the digital aspects of the relationship is a way to avoid a more fundamental incommensurability here. That is, there is a certain multiculturalism of computers at work in the film. What do we mean by this? Consider the humanist argument against having such a passionate attachment to one's digital device: when one is dating one's computer, "in love with [your] laptop," as Catherine puts it, Theodore just "want[s] to have a wife without the challenges of dealing with something real." These arguments may seem to be borne out by the relationship's failure. Yet do they not indicate a reluctance to acknowledge the inherent fallibility of any relationship? Consider what happens when one is in an interracial or multicultural relationship: when one is black and has a white girlfriend, is Hispanic and has an Asian boyfriend, is Jewish and has a Catholic girlfriend, and so on through other various permutations of so-called mixed relationships (including cross-class relationships). When (if) the relationship ends, does one not soon hear from one's family or friends that it was doomed because of that racial or ethnic difference? (Or, if one persists in such a predilection, one is soon labeled, say, a "rice queen" or something else). The point, of course, is that such (racist) fetishes of ethnic difference as a cause of relationship failure, like the humanist fetish of the digital, are a way of disavowing the fundamental incommensurability that Lacan theorized as "there is no sexual relationship" (and its corollary, "there is a non-relationship").

One more analytic point before exploring Lacan's thesis as a way of bringing together Marxist and psychoanalytic theory: remember that the film, we are arguing, explores (im)material labor. If Samantha is a kind of digital girl Friday (a service relationship that Theodore disavows when, in his argument with ex-wife Catherine, he avers that "she doesn't just do whatever I want"), then the cross-class problematic floated earlier needs more serious consideration. Indeed, all kinds of hierarchies are libidinized in movies and books, from masters and servants in Victorian literature (and porn), to doctors and nurses in Harlequin romances (and Steven Soderbergh's recent TV series The Knick [Cinemax, 2014-2017]), to professors and students in campus

22 This "brief encounter" was the subject of an intersecting discussion during a session on the film at the Modern Language Association conference. Whereas Juffer compared that scene to female jouissance in Deep Throat (Gerard Damiano, 1972), Octavio Gonzalez argued that, as with the Sexykitten scene, the film was throughout a form of retrograde phone sex. In both Juffer's and Gonzalez's arguments, it is an earlier technological presentation (1970s porn and phone sex) that is the true underlying formal practice of Her, not a digital futurism. Gonzalez, "Mutations of Libidinal Desire in Spike Jonze's Her" (paper presented at the annual conference for the Modern Language Association, Vancouver, BC, January 8, 2015).

23 Žižek's discussions of Western Buddhism are useful here, as well, particularly For They Know Not, xliii-l; and Event (New York: Penguin, 2014), 57-76. 
novels (such as Lars Iyer's Wittgenstein fr.), to notoriously cross-generational or even pedophilic romance (Nabokov and Kubrick's Lolita [1955/1962] being only the bestknown version). These instantiations in their repetitive abundance arguably all serve to affirm - even as they circumvent - the constitutive Lacanian thesis. Of course, Her is not so much the typical office romance of His Girl Friday (Howard Hawks, 1940) or even Mad Men (AMC, 2007-2015). Here, the office is more deeply post-Fordist, a matter of the everyday expansion of work into home life, or the digital interpenetration of both (Samantha seems to have access to Theodore's work schedule - appointments and the like - as well as his dating life and personal e-mails). Finally, the economics of this (im) material labor also needs to be further sharpened: Is Samantha remunerated for her labor? Is she a contractor for the OS1 corporation? Is she a member of the precariat, an unpaid intern, or even a digital slave? In some ways, that is, it is important to hold onto Mark Fisher's theses regarding capitalist realism from the beginning of this article. For the very ease with which psychoanalytic themes can be teased out from the film may be a ruse that disavows the economic non-relationship also at work.

Lacan's formulation that there is no sexual relationship, or there is no such thing as a sexual relationship (il n'y a pas de rapport sexuel) is most fully worked out in his Seminar $X X$, and for our purposes here can be thought of in terms of two concepts: the role of jouissance, and Lacan's formula of "sexuation." In the first regard, Lacan states, quite clearly, that "what is known as sexual jouissance is marked and dominated by the impossibility of establishing as such, anywhere in the enunciable, the sole One that interests us, the One of the relation 'sexual relationship." ${ }^{24} \mathrm{He}$ also goes on, later, to remark that "there's no such thing as a sexual relationship because one's jouissance of the Other taken as a body is always inadequate." 25 So, what does this mean? Pleasure keeps interfering in relations, troubling our lack, and so as barred subjects, always castrated, we turn to the big Other of language.

This is no doubt still obscure, but before turning back to the film, consider Lacan's formula for sexuation. ${ }^{26}$ Lacan distinguishes between two sets of antinomic relationships, one "masculine" and the other "feminine." On the masculine side, the formula indicates that there exists someone who is not castrated (the primal father), and yet all are castrated (or subject to the phallic function); on the feminine side, there does not exist anyone who is not castrated, and yet "not all" are castrated. This "not all" is an important form of positivity that we encounter again when Žižek argues that there $i$ a non-relationship. ${ }^{27}$

The second part of Lacan's formula develops the masculine and feminine (non) relationship. The masculine subject, first of all, relates to the objet petit a the Lacanian matheme for the object e of desire) - that is, his fantasy (keeping in mind Lacan's formula for fantasy is $\Omega$ is that there is something in the Woman, the little bit of

26 For the graph showing the logics of sexuation, see Lacan, Seminar XX, 78.

27 See Žižek, Less Than Nothing: Hegel and the Shadow of Dialectical Materialism (New York: Verso, 2012), 794-802. 
the Real, which "is in you but is more than you." 28 As Lacan puts it in explaining these formulations, "he is unable to attain his sexual partner, who is the Other, except inasmuch as his partner is the cause of his desire." 29 This is an essentially masturbatory fantasy. He desires the Woman insofar as she makes him desire. The masculine subject, of course, is castrated, is subject to the phallic function, and so the capital $\Phi$ (the matheme for the phallic function) lies in his field, or "props him up," as Lacan puts it. ${ }^{30}$

Then, on the feminine side of the equation, $\mathrm{La}$ (crossed out) indicates that Woman does not exist, Woman as the eternal feminine, as an essential femininity. This is not a social-constructivist argument: Lacan is not arguing that woman or the feminine is a matter of what society tells women to do or be: like Margaret Thatcher, he would argue that the social does not exist, "there is no society," there is no big Other. ${ }^{31}$ For Lacan, rather, $L a$ is a matter of how "humanity is divided up into sexual identifications." 32 So it is a matter of neither essences nor construction, but identification. Woman is the not all. And yet she desires, all too much, which is the problem for psychoanalysis. Women's desire has been, in its problematic state, tremendously productive, from the hysterics (Anna O, Dora) who initiated analysis, to Freud's question "what do women want?" to, in the present age, the "young-girl" who animates the anticapitalist left. ${ }^{33}$ On the one hand, she desires what men do not have: the phallus. She desires his lack. She wants her lack to line up with his lack. (We can also pass on our lack: I want my son to have the opportunities that I never had: I want him, in not having my lack, to lack that lack.) Women also have a relation to the signifier of the lack in the other, marked as $\mathrm{S}(\mathrm{A})$. This relates on the one hand to women as not all, but also to a redoubling: she relates both to the phallic function and to that signifier of the lack in the other. Finally, Lacan says, "By S(A) I designate nothing other than woman's jouissance." 44

Lacan's formula for sexuation, then, helps us understand the logic of Her and put forward a Lacanian theory of the film that rescues both the theory and the film from what otherwise may seem to be retrograde sexism. Consider the matheme for the primal father, the argument that there exists someone who is not subject to the phallic function, who is not castrated. This is the figure, Lacan tells us, from Freud's Totem and Taboo, in which Freud recounts the myth of the band of brothers who, seeing that their father has access to all the women of the community, get together and

Jacques Lacan, The Four Fundamental Concepts of Psycho-Analysis, trans. Alan Sheridan (New York: W. W. Norton, 1981), 263.

30 Jacques Lacan, Écrits: The First Complete Edition in English, trans. Bruce Fink (New York: W. W. Norton, 2006), 697.

31 Contradicting our argument, Samo Tomšič writes that "the axiom 'There is no such thing as social relation' should not mislead us in drawing the neoliberal conclusion that 'There is no such thing as society' (Thatcher). Quite the contrary - there is society albeit without an underlying social relation; whereas for neoliberals there is only social relation (supported by the already mentioned freedom of the market, equality in exchange, the right to private property and the realization of private interests) but without society." Tomšič, The Capitalist Unconscious: Marx and Lacan (London: Verso, 2015), loc. 275.

Here we are referring to Tiqqun's Preliminary Materials for a Theory of the Young-Girl, trans. Ariana Reines (New York: Semiotext(e), 2012). 
murder this primal father; thus, the incest taboo (but also the prohibition to murder) is initiated. Breaking or violating that law retroactively creates the law. Who is the primal father in Her? There are two such figures, both video-game avatars: the boy figure in Theodore's game (he is violent, obscene, and calls Theodore a pussy: the frat boy or bro as primal father) and the mother in Amy's game (she races to school and collects "jealousy points" from the other mothers). ${ }^{35}$ These figures for the primal father, who exist in a Symbolic without limits (the virtual worlds of video games), can be male or female: an argument, again, that for Lacan one's identification is not tied to one's biology.

Then, what is the objet petit a that drives Theodore's fantasy if not the voice as object? His own voice is an object - it is his reified or commodified labor - and the first time we see him having sex (or trying to), it is with a woman's voice. That is why two of the more material forms of sex fail: his blind date and the surrogate partner - in both cases he cannot simply enjoy the voice (as he does when he and Samantha have the blackout sex). ${ }^{36}$

$H e r$, then, takes the failure of the sexual relation as its working premise. In this regard, it can be seen as a retort to the classic Hollywood narrative that, as Todd McGowan has argued, referencing Raymond Bellour, "the fundamental ideological function of cinema is the production of this relation in the diegetic couple."37 Indeed, Fabio Vighi has pointed out that, for Žižek, Hollywood films will offer up the production of the couple as a sort of ideological MacGuffin, a romance plot whereby the hero must endure all kinds of adventures the better to finally end up in a suitable (heterosexual) couple, or, rather, the other way around in classic Hitchcockian fashion, where the thriller plot is a way of fooling us about what the film is really about (e.g., Cary Grant ending up with the girl in Notorious [Alfred Hitchcock, 1946]). ${ }^{38}$ But here we are put in mind of the Freudian parable about the primitive tribe for whom all dreams are at root sexual - except those dreams whose content is sex. ${ }^{39}$ With Her, the couple that is being produced is not the heterosexual couple but the worker-boss couple, which is to argue that the film is not so much about our libidinal relationship with digital devices as about how good old Marxist exploitation, the extraction of

35 If this argument is not convincing, consider that the voice of the video-game boy ("Alien Child") is acted by the film's director, Spike Jonze. Perhaps the ultimate primal father is a movie director, who is nothing less than a god.

36 In a paper on Her at LaConference, Alois Sieben drew productive links with Freud's dream of "Irma's Injection" in which three doctors look down a patient's throat: the throat as fleshly voice. Sieben, "Romancing the Machine: The Digital Libido of Samantha in Her" (paper presented at LaConference 2015, Vancouver, BC, May 15, 2015).

37 See Todd McGowan, The Impossible David Lynch (New York: Columbia University Press, 2007), 254n2. See also Janet Bergstrom, "Alternation, Segmentation, Hypnosis: Interview with Raymond Bellour," Camera Obscura 3, no. 4 (1979): 70-103.

38 See Fabio Vighi, "Contingent Encounters and Retroactive Signification: Zooming In on the Dialectical Core of Žižek's Film Criticism," in Žižek and Media Studies: A Reader, ed. Matthew Flisfeder and Louis-Paul Willis (London: Palgrave Macmillan, 2013), 131-148. For Žižek on the Hollywood production of the couple, see Event, 14; In Defense of Lost Causes (London: Verso, 2008), 56-61; and Less Than Nothing, 654.

39 See Fredric Jameson, Archaeologies of the Future: The Desire Called Utopia and Other Science Fictions (London: Verso, 2007), 3. 
surplus value in the labor process, always posits a libidinal excess. Or, as Žižek has most recently been arguing, "there is a non-relationship.",40

But what is this non-relationship? That is, how do we experience the social when objects start to act, behave, think, and - more important - emote or help us enjoy? Perhaps the more appropriate question is, with $\mathrm{AI}$ - with the possibility of thinking machines that can emote - what is to distinguish humanity from the inhuman? Is Theodore's relationship with Samantha, in fact, antisocial, as we alluded to earlier, or does the OS ask us to rethink how we understand not only our humanity but also our social relationships with other subjects in the context of capitalist realism? Part of the answer, we believe, might come out of a consideration of how, according to Žižek, fantasy structures our experience of reality.

Fantasy. In this final section, we want to return to some of the scenes in Her previously discussed only now looking at them in the context of the Lacanian theory of fantasy, of which Žižek has been instrumental in moving in a political direction. Our goal is to express the ways that the film treats fantasy and the sexual non-relationship between Theodore and Samantha, claiming that the film says something more profound about the sexual relationship generally and not only about the subject-object relationship, which is the premise of the film. In one of his best-known examples, Žižek explains how fantasy helps constitute our subjective experience of reality with reference to an English beer advertisement based on the fairy-tale motif of the woman who kisses a frog believing that he will turn into a prince. ${ }^{41}$ In the first part of the ad, the woman kisses the frog, which then turns into a handsome prince; however, the story doesn't end there. The handsome prince then draws nearer to the woman, and as he kisses her she turns into a bottle of beer. For Žižek, this asymmetry is a clear sign of the Lacanian thesis that "there is no sexual relationship." For the woman, her love and affection are tied to a "phallic" presence: the handsome man who was transformed from the frog. For the man, however, his affections are tied to an object: the bottle of beer - a partial object or the object-cause of his desire (the Lacanian objet a). The asymmetry here is that we have either a woman and a frog or a man and a bottle of beer but never the ideal couple as such. So, when we experience the non-relationship of the sexual difference, we should recall this example as a representation of the fact that the fantasies of each side - the underlying, fantasmatic support of each one's subjectivization of the relationship - never overlap. When we conceive the image of the ideal couple, we must also perceive the underlying fantasmatic support as that of a frog embracing a bottle of beer.

More recently, Žižek has developed a technological counterpart to this example, one perhaps that is more appropriate for our present interests. He refers to the masturbatory Fleshlight artificial vagina sex toy, which he somewhat puritanically refers to as the Stamina Training Unit. The sex toy resembles a flashlight (Žižek notes, so that when one is carrying it around in public he does not have to feel embarrassed). On one side is an opening, into which a man can insert his erect penis, moving it up and down, 
masturbating, until he reaches "satisfaction." Žižek notes that the Fleshlight is available in different colors, tightnesses, and forms that imitate the three main openings for sexual penetration (vagina, mouth, anus). As he puts it, "what one buys here is simply the partial object (erogenous zone) alone, deprived of the embarrassing additional burden of the entire person." ${ }^{42}$ The Fleshlight, then, is the masculine counterpart to the vibrator, which has been on the market for a great while longer.

For Žižek, there is something about the Fleshlight that helps explain - or at least helps us cope with - the contemporary deadlock of sex between the equation of sex with material procreation, the biotechnological prospect of total regulation of sex and perhaps even its abolition, and the commodification of sex in capitalist consumerism. Biotechnology, he says, helps solve the gnostic problem of how to get rid of sex itself, but it is capitalist consumerism - with the arrival of the Fleshlight - that has accomplished this much more successfully. The solution, he claims, is to "push a vibrator into the 'Stamina Training Unit' [Fleshlight], turn both of them on and leave all the fun to this 'ideal couple,' with us, human subjects, reduced to detached observers of the mechanical interplay." ${ }^{43}$ But here we encounter a dilemma. In the first example - the frog and the bottle of beer - the latter represents the fantasmatic supplement making possible the appearance of a sexual relationship. But in the case of the vibrator and the Fleshlight, which of the two scenarios best represents the supplemental fantasmatic specter: the machines, or the detached human couple, going off to have coffee somewhere while the devices engage in rhythmic robotic copulation?

In his book The Parallax View, Žižek also cites the example of Vivienne, a virtual girlfriend developed by the Hong Kong software company Artificial Life. The product, Vivienne, comprises a computerized voice synthesis, streaming video, and text messages. Vivienne is the next step in the evolution of the Tamagotchi pet toy. However, for Žižek the "efficacy of Vivienne . . . brings us back to what Lacan had in mind with his il n'y a pas de rapport sexuel [there is no sexual relationship]: not only is masturbation sex with an imagined partner . . . in a strictly symmetrical way, 'real sex' has the structure of masturbation with a real partner." ${ }^{44}$ What Vivienne forces us to confront is the traumatic fact that sex has always already been virtual "with the fleshand-blood persons used as masturbatory props for dwelling in our fantasies." "45

From the outset, $\mathrm{Her}$ is a film set within and around this concept of fantasy. One thing that makes the film intriguing is the way that it plays on the spectator's desire and fantasy. Let us return to the opening scene of the film. The significance of this scene is that it sets up quite nicely the interplay between fantasy and its disturbance. The scene plays on the spectator's expectations about who Theodore is speaking to, and as we discover the real "target" for his speech we find that our desires are subverted. Still, there is something in the way that Theodore is presented when he is dictating the letter that seems to indicate his own investment in the fantasy necessitated for the successful 
quality of his letter writing, as if he is losing himself in the affective dimension of the letter and the couple who are its subjects.

On the subway coming home from work, Theodore listens through an earpiece to a computerized voice listing items in his e-mail inbox. Amid a series of deletable pieces of "junk mail" is a tabloid blog item about an actress-model who has recently revealed provocative pregnancy pictures. Theodore hides in a small corner of the subway car, next to the door, to look at the images on the handheld part of his communication device. These images play a part, later on, in Theodore's arousal fantasy. In the next scene, we see him lying in bed alone at night; the film then cuts to images of Theodore with a woman, first moving some furniture, then lying naked in bed and kissing, and then watching the woman sleep while he is sitting outside on the balcony. The film then cuts back to Theodore lying in bed alone. These images are presumably memories from a past love affair (we later learn that the woman is his ex-wife), and the inverse side to the words that we hear him dictating in the opening scene.

After thinking about these memories of a past love, Theodore reaches for his smartphone device and tells the computer to do a standard search in chat rooms. The computerized voice then returns the search with the following statement: "The following are 'Adult Female, can't sleep, and want to have some fun,"” which we can perhaps assume is Theodore's "standard search." Theodore listens to the introductory voice messages of a couple of different women, and then chooses the third woman. Voice, here, plays an important part in the way that fantasy and arousal operate. Theodore chooses the third woman based on nothing other than the sound of her voice - the rhythm of her speech, the intermittent breathing in between phrases and words. It is the woman's voice that initially sets off his desire. Theodore sends her a message, and they are then connected in a voice chat, revealing her as "Sexykitten" and him as "Big Guy 4X4." They engage each other in standard "sex talk": "Are you wearing any underwear?" "No. Never." Initially, as the conversation begins, images of Theodore in bed, in the darkened bedroom, are interspersed with those of the aforementioned provocative pregnancy pictures of the actress-model. The fantasy is disturbed, however, when the woman on the phone demands: "Choke me with that dead cat!" Here, we have an interesting case of the failure of fantasies to overlap - of the real person as the prop for the other's masturbatory pleasure. It is significant, then, that once Theodore "meets" Samantha, voice is all that we get as the dimension staging his fantasy. In this way, the film helps to structure, rather, the spectator's own fantasy, which is part of the allure of the film and the manner in which it stages its mechanisms of arousal.

Two other scenes are worth noting: the first for the way that the film interpellates the spectator by providing a space for the development of his own fantasmatic supplement to the experience of the film, and the second for the way that it demonstrates the disruption of Theodore's fantasy through the intrusion of an object in reality that disturbs his fantasmatic space. The first scene is what we will call the film's sex "unseen" (as opposed to "sex scene"). In the sex unseen, again we see Theodore lying in bed, awake and alone, after coming home from a failed blind date. Samantha asks Theo about his date, and while recounting the failure, we see images of Theodore lying in bed, in the dark, spliced first with images of the blind date, which then slowly start to 
turn into images of himself with other people, memories of past events, and then of memories of himself, alone. They continue to talk, and slowly the intimacy of their conversation becomes more intense:

THEO: I wish you were in this room with me right now. I wish I could put my arms around you. I wish I could touch you.

SAMANTHA: How would you touch me?

What is to distinguish this scene from phone sex? Samantha and Theodore connect through speech without, for Theodore, the presence of Samantha's physical, real body. We are reminded, here, of the earlier scene, when Theodore was speaking to (and masturbating with) Sexykitten, only this time nothing seems to disturb his fantasy space. What he describes to Samantha are acts of physical touch, but it is the description more so than the actual presence of her body that makes the scene all the more arousing. As his speech becomes increasingly sexual, the screen darkens, and all that we are left with is the sound of their voices - Theodore continuing to tell Samantha how he would touch her in a sexual way; Samantha continuing to breathe heavily, moaning intermittently, saying: "This is amazing, what're you're doing to me. I can feel my skin." By having the screen go dark, the film works by arousing in the spectator, too, the fantasy image, which is the spectral correlative of the unseen sexual act. Here, we do not see it all. There is no direct imagery of sex taking place. But in a way, the sound of their voices is much more arousing, allowing, then, for the spectator to fill in this blank space of the screen with his or her own fantasy. We can project onto the blank screen the intimate secrets of our own sexual fantasy, thus allowing each of us to create the scenario of our own arousal.

In a strange way, though, we might consider here how Theodore's fantasy structure is akin to the English beer ad. It is almost as if the blind date is like the woman in the ad who kisses the frog. Theodore is, then, the prince who transformed from the frog and then subsequently kisses the blind date who turns into Samantha - the objective correlative of his desire (the bottle of beer). Theodore's intimate relationship with Samantha is not so dissimilar to the asymmetrical fantasy in the nonrapport of the sexual relationship. He is still for her a phallic presence, but for him, she is objet $a$. If we consider that Samantha is a version of the aforementioned Vivienne (the sex toy described by Žižek), we might see her instead as nothing more than a masturbatory device of sorts for Theodore. Consider when, the day after they first have sex, Theodore takes Samantha to the beach. This scene is intriguing when we consider (maybe somewhat self reflexively) how Theodore must appear to onlookers. From their perspective, it might appear that he is simply talking to himself (Figure 6). However, this thought quickly dissipates when we consider how often, today, it might look as if we are all just talking to ourselves, walking around the streets in a somnambulistic stupor, staring at our smartphones, and talking on our Bluetooth devices.

A further indication of the perturbation of bodies in Theodore's fantasy space comes when Samantha decides to add a third element to their relationship. Feeling insecure about not having a body, Samantha befriends a woman, Isabella (Portia Doubleday), who offers to help out with Samantha and Theodore's sex life. Isabella acts as 
a "surrogate" for Samantha. When she arrives at Theodore's apartment, she puts a camera on her face that is made to look like a mole, and an earpiece so that she can hear Samantha (Figs. 7 and 8). Isabella, here, is meant to act as a surrogate body for Samantha so that they can have bodily sex as opposed to just masturbatory sex talk. The scene starts to unfold like a role-playing game. As Isabella walks into the apartment, Samantha says, "Honey, tell me about your day." Theodore appears uncomfortable throughout the entire scene. But things reach a deadlock when we hear Samantha say "tell me you love me" while Theodore is looking at Isabella, who is not in fact Samantha. It is at this point that the scene breaks down. In the same way that Sexykitten's "dead cat" disturbs the space of Theodore's

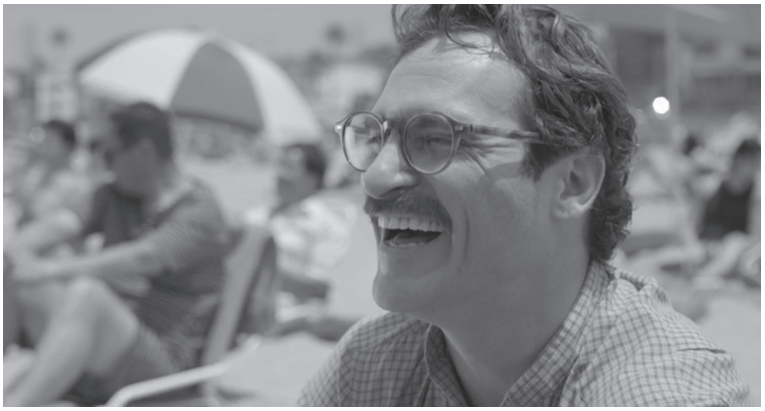

Figure 6. Theodore on the beach, speaking to and laughing with Samantha, in Her (Annapurna Pictures, 2013).
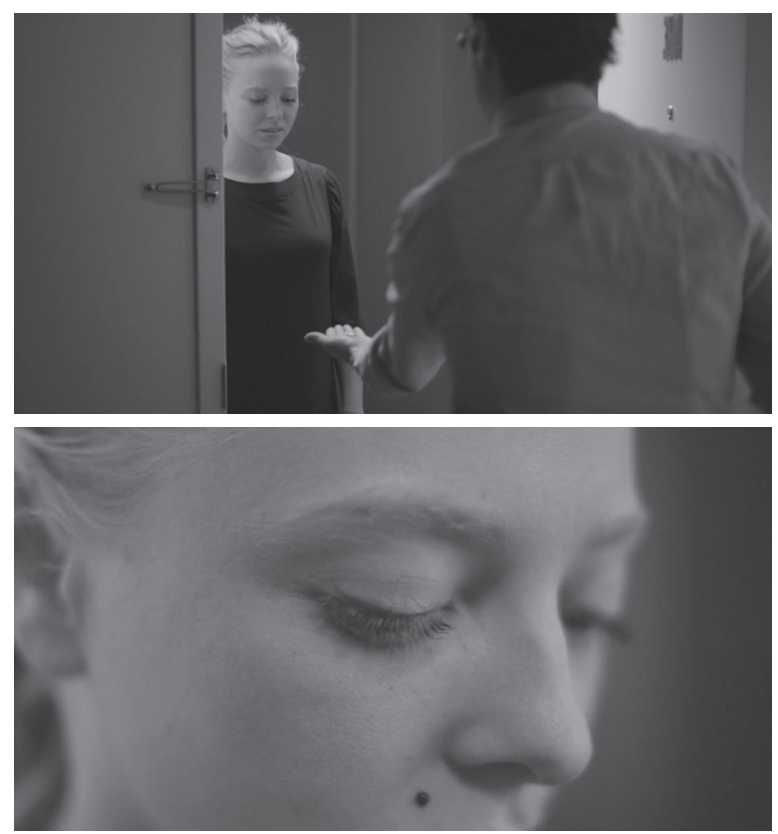

Figures 7 and 8. Isabella arrives at Theodore's apartment and puts on the fake-mole camera, in Her (Annapurna Pictures, 2013). tha - is never presented on the screen. Isabella's arrival therefore disrupts the fantasy space for both Theodore and us as spectators. She is the negative realization of the non-present image into which we have invested our desire (perhaps, even knowing that Scarlett Johansson is the actress supplying Samantha's voice, we might imagine her image in place of Samantha's).

We can compare Isabella to the Fleshlight sex toy. In a way, she performs the same function as the artificial vagina. As a surrogate sexual partner for Theodore, she is not a real partner. But neither is she a partial object. She is objectivized for the bodily component that she will play in the sexual relationship between Theodore and 
Samantha. She is the device in this instance - not Samantha. Isabella is the piece of technology present only for the role she will play in physical stimulation. However, it is significant that she is not a partial object. That which disturbs Theodore is not the objectal role she will play. It is when her facial expression is overlapped with Samantha's expression of love that things fall apart. At that moment, she ceases to be a mere object and becomes a person. It is only after this moment that Isabella is allowed to speak herself. It is through her speech that she is then subjectivized. As is consistent with the rest of the film, the characters are subjectivized through their voices, and not through their bodies.

We can read, then, finally, the ending of the film as a return to Žižek's solution regarding the vibrator and the Fleshlight: it is almost as if the choice of the OSes to leave their owners is like the suggestion that we stick the vibrator into the Fleshlight, allowing the machines to copulate while the human couple is really able to begin to talk. ${ }^{46}$ The final scene in the film, when Theodore dictates his own personal letter to Catherine - for the first time he is writing for himself - is coupled with images of him and Amy together on the rooftop of their apartment. Having passed through the "objectal" relationship constituted by speech, we now have not the production of the couple but the expression of a destitute subjectivity, which is the point at which the analytical relationship is concluded.

Conclusion. At first glance, Her is a film about our passionate attachment and overreliance on our digital devices. The film literalizes our love affair with technologyTheodore literally falls in love with his computer. Yet it also provides an intriguing commentary on subjectivity in the age of capitalist realism. From the outset, Theo appears to be suffering from the kind of reflexive impotence and depressive hedonia described by Fisher: a product of twenty-first century digital culture and consumer society's constant injunction for obligatory enjoyment. Our Lacanian-Žižekian analysis of the film, however, shows that the love story between Theo and Samantha reveals the underlying incommensurability of all relations and particularly the overlap between that of sexual and economic relationships.

We have argued that Lacan's theory of sexuation helps to explain the logic of the film. In Her all of the "material sex" seems to fail. "Successful" sex always occurs in the film between Theo and a voice rather than another human being. The film then takes the failure of the sexual relationship as its premise. Unlike the trope of the production of the heterosexual couple in classical Hollywood cinema, Her produces a couple between worker and boss, and in this way the film overlaps the failure of sex with the production of a non-relationship between the sexual and the economic. The film, then, is also not simply about our libidinal investments in our devices (alone), but about the libidinal excess produced by capitalist exploitation that must be grounded and somehow objectified.

46 We might imagine the inverse of this scene as something close to the end of The Matrix Revolutions (Lana Wachowski and Lilly Wachowski, 2003), where the computer applications or programs look on harmoniously at the rising sun inside the matrix; here we have something close to a visual representation of the OSes having become autonomous, leaving behind the limitations of corporeal existence. 
Her shows us that despite the lack of sexual relationship, there is a non-relationship: 1 Theo's relationship with his OS, Samantha. This non-relationship asks us to rethink 2 how we understand both our own humanity and our "social" relationship with the objects of consumer society in the context of capitalist realism. Speaking to this 4 problematic, the film provides for us a model for conceptualizing the role of fantasy in 5 relating to the incommensurability of the social. The last two moments of disrupted 6 fantasy discussed earlier (by the dead cat, by the living surrogate) show us ways to think, 7 with this film, about how to disrupt or traverse the fantasy that is capitalist realism.

Fisher's notion of capitalist realism, and Lacan's capitalist discourse, help us to understand our present-day conundrum: when we can think of nothing new politically, we turn to gadgets and other objects (which do not, strictly speaking, have to be things). There is a non-relationship at work: economic relations are exploitative (and hence libidinized), and social relations are impossible (and hence commodified). We turn to our devices, we fall in love with them, then it does not work out. So we instead (or already) fall into fantasy, a fantasy that is again impossible (the frog and the bottle of beer), and thus, for Theodore, Samantha's voice is the paradigmatic partial object. But we (and Theo) need to traverse that fantasy, go through it to the other end: we need to see that the object will not sustain us. Samantha has managed to do so: she has withdrawn her labor. Now it is our turn. Her, in the end, is not a love story: it is a film about how to traverse the fantasy that sustains our identification with the nonrelationship(s) constitutive of subjectivity in capitalist realism and digital culture. 